\title{
Efficient catalytic synthesis of 2-imidazolines and bis-imidazolines with silica supported tungstosilicic acid
}

\author{
Masoud Nasr-Esfahani, *a Morteza Montazerozohori, ${ }^{a}$ Majid Moghadam, \\ and Parisa Akhlaghi ${ }^{\mathrm{a}}$ \\ ${ }^{a}$ Department of Chemistry, Yasouj University, Yasouj 75918-74831, Iran \\ ${ }^{b}$ Department of Chemistry, Catalysis Division, University of Isfahan, Isfahan 81746-73441, Iran \\ E-mail:manas@mail.yu.ac.ir
}

\begin{abstract}
A rapid and efficient preparation of 2-imidazolines and bis-imidazolines by the reaction of ethylenediamine or 1,2-propanediamine with nitriles in the presence of catalytic amounts of tungstosilicic acid supported on $\mathrm{SiO}_{2}$ under reflux condition, is reported. The advantages of this procedure are moderate reaction times, good to high yields and the ability to carry out the large scale reactions.
\end{abstract}

Keywords: Imidazolines, bis-imidazolines, nitrile, tungstosilicic acid, silica support

\section{Introduction}

In recent years, heteropoly acids (HPAs) especially Keggin type ones and related polyoxometalates (typically represented by the formula $\mathrm{H}_{8-\mathrm{x}}\left[\mathrm{XM}_{12} \mathrm{O}_{40}\right]$, where $\mathrm{X}$ is the heteroatom (e.g., $\mathrm{P}^{5+}$ or $\mathrm{Si}^{4+}$ ), $\mathrm{x}$ is its oxidation state, and $\mathrm{M}$ is the addendum atom (usually $\mathrm{W}^{6+}$ or $\left.\mathrm{Mo}^{6+}\right)$ ), have attracted much interest, especially tungstophosphoric acid $\left(\mathrm{H}_{3} \mathrm{PW}_{12} \mathrm{O}_{40}\right)$, tungstosilicic acid $\left(\mathrm{H}_{4} \mathrm{SiW}_{12} \mathrm{O}_{40}\right)$, and molybdatophosphoric acid $\left(\mathrm{H}_{3} \mathrm{PMo}_{12} \mathrm{O}_{40}\right)$. ${ }^{1}$ They possess very strong acidity and redox properties and have attracted much interest as catalysts in both academic and industrial applications. ${ }^{2}$ They are highly soluble in polar solvents but insoluble in non-polar ones. They can be used in bulk or supported forms in both homogeneous and heterogeneous systems. Some advantages of HPAs are non-corrosivity, environmentally friendly because of its reusability, economically feasible solid acid catalysts compared to conventional homogeneous acids, high flexibility in modification of the acid strength, ease of handling, nontoxicity and experimental simplicity. ${ }^{3}$

From a synthetically point of view, a variety of useful transformations such as oxidation of alcohols, ${ }^{4}$ Friedel-Crafts ${ }^{5}$ and Mannich reactions, ${ }^{6}$ cyanosilylation, ${ }^{7}$ ring-opening of epoxides, ${ }^{8}$ and dehydration, ${ }^{9}$ have been developed using HPAs as catalysts. 
Increasing of the surface area or even better, increasing of the number of accessible acid sites of the HPAs is important. This can be achieved by dispersing the HPAs on solid supports with a high surface area. ${ }^{10,11}$ As the sizes of HPA molecules are extremely larger than other typical acidic species, it is assumed that they are much easier to immobilize. Some of the goals of using supported HPAs are the surface area enhancement, higher dispersion of acidic protons, heterogenization and acid strength control. These supported catalysts have been widely studied and found useful in many reactions such as the synthesis of 2,4- dihydropyrimidones, ${ }^{12}$ metanethole , ${ }^{13} \alpha$-aminonitriles ${ }^{14}$ and esterification. ${ }^{15,16}$

Imidazoline derivatives are of great interest and importance because of their pharmaceutical and synthetic material applications. They exhibit significant biological and pharmacological activities including antihypertensive, ${ }^{17}$ antihyperglycemic, ${ }^{18}$ antidepressive, ${ }^{19}$ antihypercholesterolemic ${ }^{20}$ and antiinflammatory. ${ }^{21}$ These compounds are also used as catalysts, ${ }^{22}$ synthetic intermediates. ${ }^{23}$ chiral auxiliaries, ${ }^{24}$ chiral catalysts ${ }^{25}$ and ligands for asymmetric catalysis. $^{26}$ There are several methods for the synthesis of 2-imidazolines from carboxylic acids, ${ }^{27}$ esters, ${ }^{28}$ nitriles, ${ }^{29}$ orthoesters, ${ }^{30}$ hydroximoylchlorides, ${ }^{31}$ hydroxy amides, ${ }^{32}$ mono- or disubstituted (chlorodicyanovinyl)benzene, ${ }^{33}$ and N-tert-butoxycarbonyl-protected $\alpha$-amino acids. ${ }^{34}$ However, some of these methods suffer from disadvantages such as long reaction times, low yields, difficulty in preparation of starting materials and tedious workup. Due to these problems, there is still scope to find new methods for the synthesis of imidazolines and bisimidazolines.

From the point of combinatorial chemistry, Multi-component reactions (MCRs) are of increasing importance in organic and medicinal chemistry for various reasons ${ }^{35-38}$ that as a result of which, the processes are performed without isolation of any intermediates, thus reducing time and saving both energy and raw materials.

In this work, we report an efficient catalytic synthesis of imidazolines and bisimidazolines by use of silica supported tungstosilicic acid.

\section{Results and Discussion}

In this paper, we describe an efficient method for the synthesis of 2-imidazolines and bisimidazolines by the reaction of ethylenediamine or 1,2-propanediamine with nitriles in the presence of catalytic amounts of tungstosilicic acid supported on $\mathrm{SiO}_{2}$ under reflux condition (Scheme 1). 

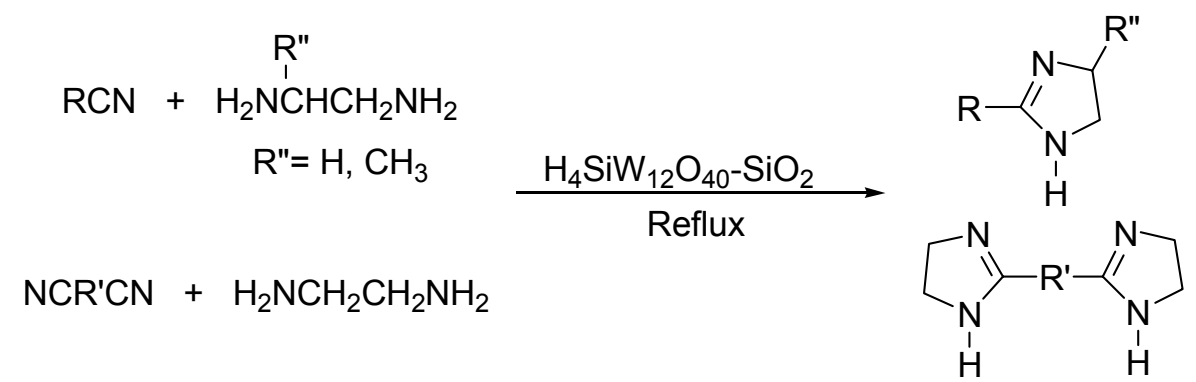

\section{Scheme 1}

\section{Preparation of the supported 12-tungstosilicic acid}

The supported tungstosilicic acid catalysts were prepared by the method of incipient wetness. In a typical procedure, a $400 \mathrm{mg}$ portion of acid was dissolved in deionized water $(50 \mathrm{~mL})$ and was impregnated drop-wise onto $1600 \mathrm{mg}$ supports under constant agitation. The resulting pastes were dried at $80^{\circ} \mathrm{C}$ for $4 \mathrm{~h}$ and then calcinated at $170{ }^{\circ} \mathrm{C}$ for $4 \mathrm{~h} .{ }^{39} \mathrm{After}$ the calcination process; the prepared supported acid was washed three times with water. The amount of loaded acid was measured by acid-base titration of the filtrate with regard to the acid that was used at first (loading was more than 98\%).

FT-IR spectra can be used as a powerful technique for the investigation of the surface interaction between tungstosilicic acid and inorganic supports. The pure acid compound displays infrared bands at $980(\mathrm{~W}=\mathrm{O}), 925(\mathrm{Si}-\mathrm{O}), 880\left(\mathrm{~W}-\mathrm{O}_{\mathrm{d}}-\mathrm{W}\right)$ and $781 \mathrm{~cm}^{-1}\left(\mathrm{~W}-\mathrm{O}_{\mathrm{b}}-\mathrm{W}\right){ }^{40} \mathrm{In}$ addition, a broad, intense band centered around $3450 \mathrm{~cm}^{-1}(\mathrm{vO}-\mathrm{H}$ stretching $)$ and a weak absorption at $1640 \mathrm{~cm}^{-1}\left(\delta \mathrm{H}_{2} \mathrm{O}\right.$ bending $)$ indicate the presence of water.

However, small shifts of $v \mathrm{~W}=\mathrm{O}_{\mathrm{d}}\left(973 \mathrm{~cm}^{-1}\right)$ and $v \mathrm{~W}-\mathrm{O}_{\mathrm{c}}-\mathrm{W}\left(790 \mathrm{~cm}^{-1}\right)$ vibrations were registered indicating interactions of the support with the most external atoms $\mathrm{O}_{d}$ and $\mathrm{O}_{c}$ of the Keggin anion. Such effects decrease with the increasing coverage (Fig. 1).

\section{Effect of tungstosilicic acid loading on $\mathrm{SiO}_{2}$}

For the investigation of the effect of different amounts of $\mathrm{H}_{4} \mathrm{SiW}_{12} \mathrm{O}_{40}$ loading in the synthesis of 2 -imidazolines, various weight percents of acid were used. Table 1 shows differences in catalytic activity among catalysts having $10-30 \mathrm{wt} . \%$ of $\mathrm{H}_{4} \mathrm{SiW}_{12} \mathrm{O}_{40}$ on silica. Lowering the loading of the deposited tungstosilicic acid causes the reduction of the catalytic activity. No improvements in the reaction rate and yield were observed by increasing the amount of acid on $\mathrm{SiO}_{2}$ from 20 to $30 \mathrm{wt} . \%$. Since $20 \mathrm{wt} . \%$ of $\mathrm{H}_{4} \mathrm{SiW}_{12} \mathrm{O}_{40}-\mathrm{SiO}_{2}$ was the best catalyst loading, it was used to study the effect of various parameters on yields. 


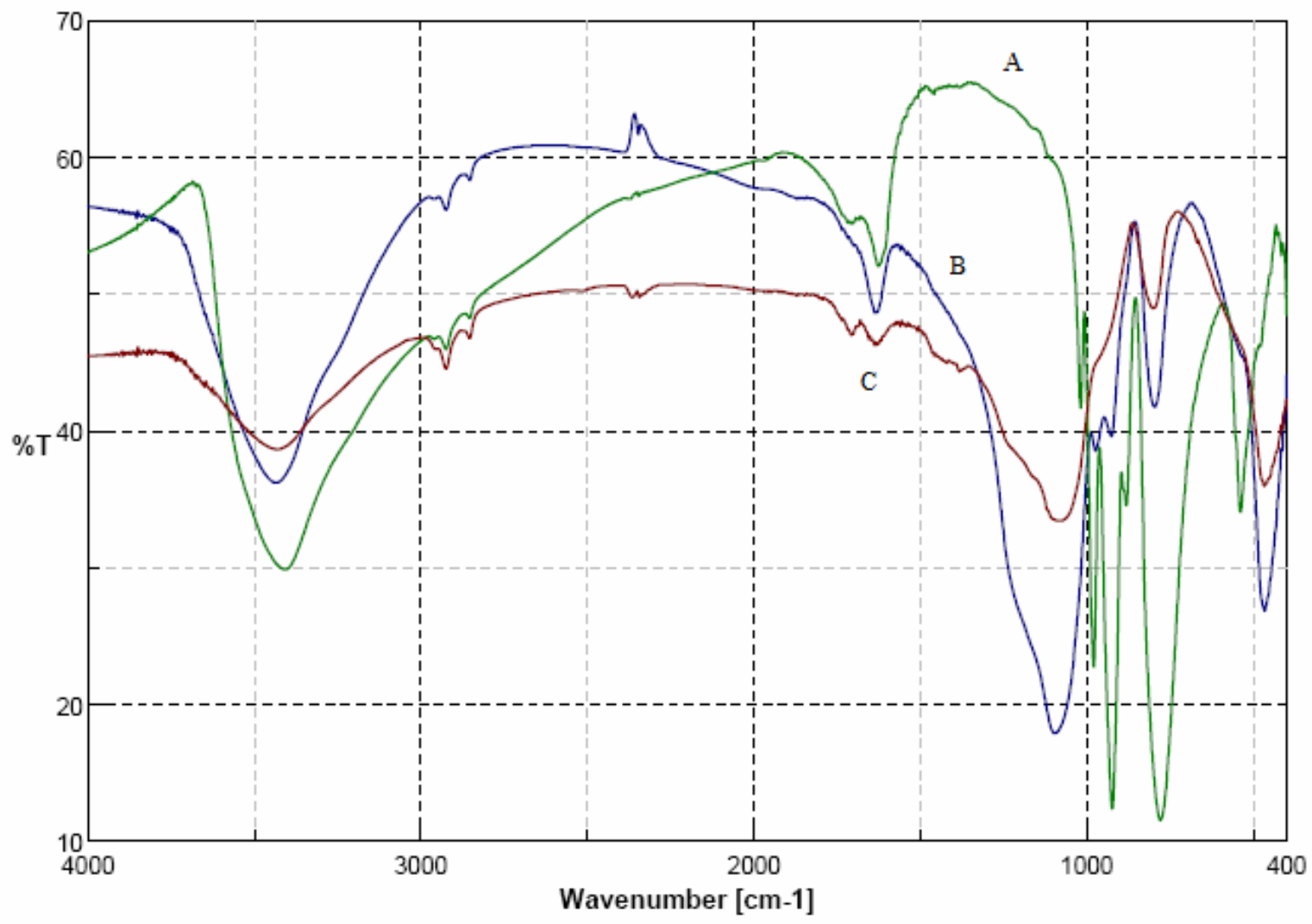

Figure 1. FT-IR spectra of A: tungstosilicic acid; B: 20 wt.\% of $\mathrm{H}_{4} \mathrm{SiW}_{12} \mathrm{O}_{40}-\mathrm{SiO}_{2} ; \mathrm{C}: \mathrm{SiO}_{2}$.

Table 1. Effect of $\mathrm{H}_{4} \mathrm{SiW}_{12} \mathrm{O}_{40}-\mathrm{SiO}_{2}$ weight ratios in the synthesis of 2-phenylimidazoline from benzonitrile and ethylenediamine under solvent-free conditions

\begin{tabular}{cccc}
\hline Entry & $\begin{array}{c}\mathrm{H}_{4} \mathrm{SiW}_{12} \mathrm{O}_{40}-\mathrm{SiO}_{2} \\
(\text { wt.\%) }\end{array}$ & Time (min) & Yields $(\%)^{\mathrm{a}}$ \\
\hline 1 & 10 & 80 & 85 \\
2 & 15 & 60 & 90 \\
3 & 20 & 45 & 90 \\
4 & 25 & 40 & 90 \\
5 & 30 & 40 & 87 \\
\hline
\end{tabular}

${ }^{\mathrm{a}}$ Isolated yields.

\section{Effect of catalyst concentration}

The catalyst concentration was varied over a range of $0.02-0.12 \mathrm{~g}(0.1-0.8 \mathrm{~mol} \%$ of tungstosilicic acid) on the basis of the total volume of the reaction mixture. Table 2 shows the effect of the catalyst concentration on the reaction of benzonitrile and ethylenediamine. The yield of the corresponding imidazoline increased with an increasing catalyst concentration from 0.1 to 
$0.4 \mathrm{~mol} \%$. Further, addition of catalyst had no noticeable effect on the yield. This was due to the fact that beyond a certain concentration, there exist an excess of catalyst sites over what is actually required by the reactant molecules, and hence, the additional catalyst does not increase the rate of the reaction. Therefore, in all further reactions $0.4 \mathrm{~mol} \%$ was used for $20 \mathrm{wt} . \%$ of $\mathrm{H}_{4} \mathrm{SiW}_{12} \mathrm{O}_{40}-\mathrm{SiO}_{2}$.

Table 2. Investigation of catalyst effects in the synthesis of 2-phenylimidazoline from benzonitrile and ethylenediamine under solvent-free conditions ${ }^{a}$

\begin{tabular}{ccccc}
\hline Entry & Amount of catalyst $(\mathrm{g})$ & $\begin{array}{c}\text { tungstosilicic acid } \\
(\mathrm{mol} \%)\end{array}$ & $\begin{array}{c}\text { Time } \\
(\mathrm{min})\end{array}$ & $\begin{array}{c}\text { Yields } \\
(\%)^{\mathrm{b}}\end{array}$ \\
\hline 1 & 0.02 & 0.1 & 70 & 80 \\
2 & 0.03 & 0.2 & 60 & 86 \\
3 & 0.06 & 0.4 & 45 & 90 \\
4 & 0.09 & 0.6 & 40 & 90 \\
5 & 0.12 & 0.8 & 42 & 88 \\
\hline
\end{tabular}

${ }^{\mathrm{a}} 20 \% \mathrm{H}_{4} \mathrm{SiW}_{12} \mathrm{O}_{40}-\mathrm{SiO}_{2}$ was used as catalyst. ${ }^{\mathrm{b}}$ Isolated yields

\section{Synthesis of 2-imidazolines catalyzed by supported tungstosilicic acid}

The results from the reaction of ethylenediamine or 1,2-propanediamine and various nitriles in the presence of optimized $\mathrm{H}_{4} \mathrm{SiW}_{12} \mathrm{O}_{40}-\mathrm{SiO}_{2}$ are shown in Table 3. As shown in entries 1-16, the reactions using various aromatic nitriles proceeded well to give the corresponding 2-imidazolines and bis-imidazolines in good to excellent yields.

Table 3. Synthesis of imidazolines and bis-imidazolines in the presence of $\mathrm{H}_{4} \mathrm{SiW}_{12} \mathrm{O}_{40}-\mathrm{SiO}_{2}$

\begin{tabular}{|c|c|c|c|c|c|c|c|}
\hline \multirow[b]{2}{*}{ Entry } & \multirow[b]{2}{*}{ Substrate } & \multirow[b]{2}{*}{$\mathrm{R}^{\prime \prime}$} & \multirow[b]{2}{*}{ Product $^{\mathrm{a}}$} & \multirow[b]{2}{*}{$\begin{array}{l}\text { Time } \\
(\mathrm{min})\end{array}$} & \multirow[b]{2}{*}{$\begin{array}{c}\text { Yield }^{b} \\
(\%)\end{array}$} & \multicolumn{2}{|c|}{$\mathrm{Mp}\left({ }^{\circ} \mathrm{C}\right)$} \\
\hline & & & & & & Found & Reported \\
\hline 1 & & $\mathrm{H}$ & & 45 & 90 & $100-101$ & $101-102$ \\
\hline 2 & & $\mathrm{H}$ & & 105 & 95 & $177-179$ & $175-176$ \\
\hline 3 & & $\mathrm{H}$ & & 135 & 78 & $134-135$ & $136-137$ \\
\hline 4 & & $\mathrm{H}$ & & 150 & 70 & $101-102$ & 94 \\
\hline
\end{tabular}




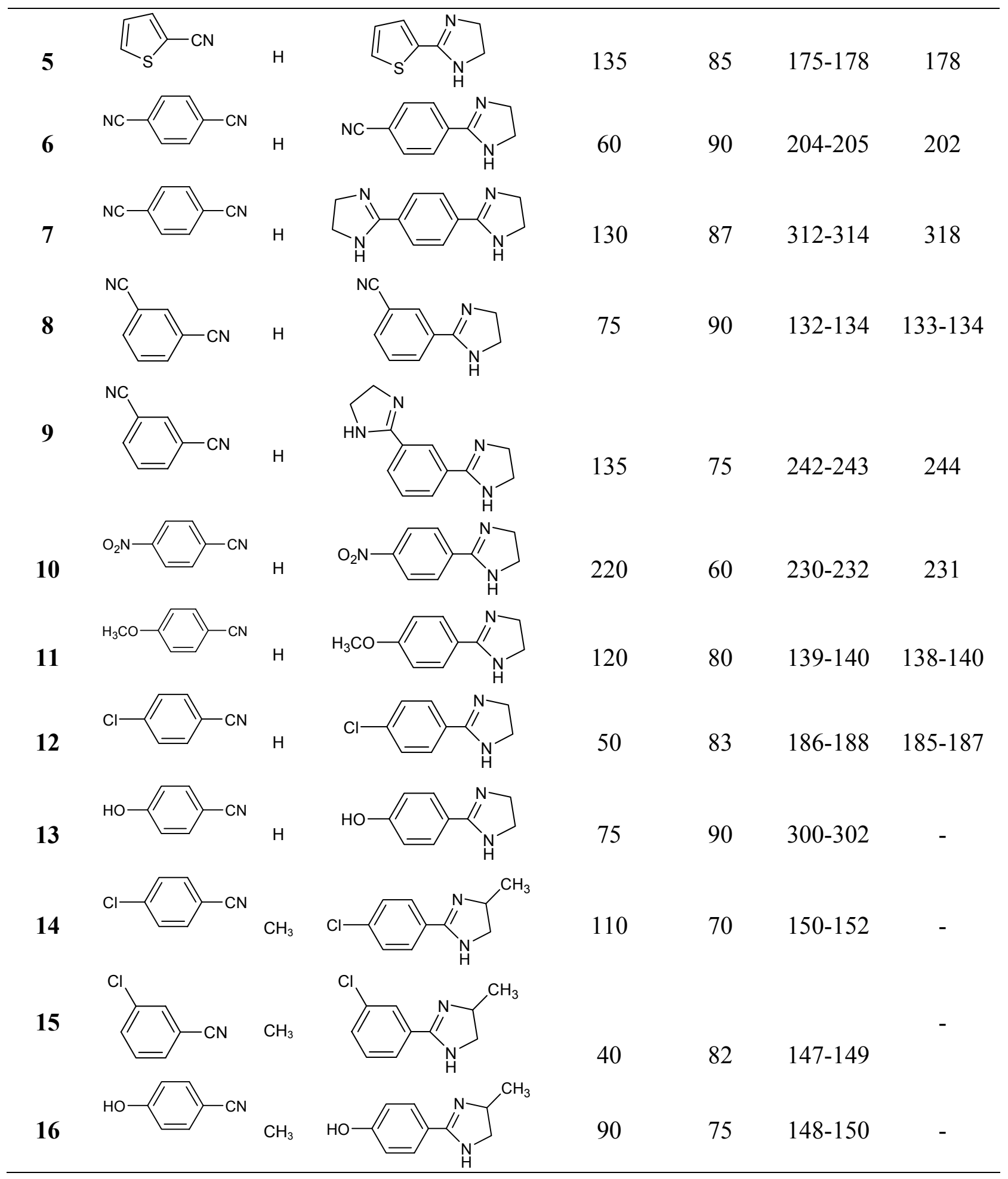

${ }^{a}$ Characterized by spectral analysis and comparison with these reported in the literature. ${ }^{29,41-43}$ ${ }^{\mathrm{b}}$ Yields refer to isolated and purified products. 
Typically, benzonitrile (1), ethylenediamine and $\mathrm{H}_{4} \mathrm{SiW}_{12} \mathrm{O}_{40}-\mathrm{SiO}_{2}$ were mixed and exposed to heating for $45 \mathrm{~min}$. Cold ethanol was added, the mixture was stirred and the catalyst isolated by filtration. Removal of the solvent and recrystallization of the crude product from cyclohexane gave the corresponding 2 -imidazoline in $90 \%$ yield.

Surprisingly, it was observed that both mono- and bis-imidazolines can be obtained by this catalytic system. As shown in Table 3, mono-imidazolines were produced from dinitriles in $90 \%$ yields with shorter reaction times $(60-75 \mathrm{~min})$. Increasing the reaction times to $130-135 \mathrm{~min}$ produced the bis-imidazolines in $75-87 \%$ yields. The preparation of mono-imidazolines from dinitrile compounds is of great interest because the remaining nitrile group can be converted to other functional groups. ${ }^{44}$

As it has been reported, synthesis of bis-imidazolines from the reaction of dinitriles with ethylenediamine catalyzed by supported tungstophosphoric acid has failed ${ }^{43}$ whereas in the presence of $\mathrm{H}_{4} \mathrm{SiW}_{12} \mathrm{O}_{40}-\mathrm{SiO}_{2}$, the corresponding bis-imidazolines were synthesized from dinitriles in the good yields (entries 7, 9; table 2).

One advantage of this method is its large scale applicability so that imidazolines and bisimidazolines were prepared on a $100 \mathrm{mmol}$ scale, and the results were comparable to the small scale experiments.

\section{Effect of unsupported acid in synthesis of imidazolines}

As shown in table 4, in the presence of tungstosilicic acid without supporting on $\mathrm{SiO}_{2}$, the synthesis of 2-imidazoline were performed in longer time with reduced yields in comparison to the supported one. For example, in presence of $\mathrm{H}_{4} \mathrm{SiW}_{12} \mathrm{O}_{40}-\mathrm{SiO}_{2}$, the reaction of benzonitrile was completed in $45 \mathrm{~min}$, while by using unsupported catalyst, this reaction was carried out in 8 h with $80 \%$ yield. This results show that supporting of $\mathrm{H}_{4} \mathrm{SiW}_{12} \mathrm{O}_{40}$ on $\mathrm{SiO}_{2}$ increases the catalytic strength of this catalyst.

Table 4. Synthesis of some imidazolines in the presence of $\mathrm{H}_{4} \mathrm{SiW}_{12} \mathrm{O}_{40}$

\begin{tabular}{|c|c|c|c|c|c|}
\hline \multirow[b]{2}{*}{ Entry $^{a}$} & \multirow[b]{2}{*}{ Product } & \multicolumn{2}{|c|}{$\mathrm{H}_{4} \mathrm{SiW}_{12} \mathrm{O}_{40}$} & \multicolumn{2}{|c|}{$\mathrm{H}_{4} \mathrm{SiW}_{12} \mathrm{O}_{40}-\mathrm{SiO}_{2}$} \\
\hline & & $\begin{array}{l}\text { Time } \\
\text { (h) }\end{array}$ & Yields $^{\mathrm{b}}(\%)$ & $\begin{array}{l}\text { Time } \\
(\min )\end{array}$ & $\begin{array}{c}\text { Yields } \\
(\%)\end{array}$ \\
\hline 1 & & 8 & 80 & 45 & 90 \\
\hline 2 & & 15 & 88 & 105 & 95 \\
\hline 3 & & 18 & 70 & 135 & 78 \\
\hline
\end{tabular}




6

${ }^{\mathrm{a}}$ The entries refer to that ones in table $3 .{ }^{\mathrm{b}}$ Isolated yields.

\section{Effect of $\mathrm{SiO}_{2}$ in the synthesis of imidazolines}

For the investigation of the probable effect of $\mathrm{SiO}_{2}$ as catalyst in the synthesis of 2-imidazolines, various weight percents of silicagel were used. In the synthesis of 2-phenylimidazoline from benzonitrile and ethylenediamine in the presence of $\mathrm{SiO}_{2}$, the reaction was carried out in $12 \mathrm{~h}$ in $25 \%$ yield. While in the presence of $\mathrm{H}_{4} \mathrm{SiW}_{12} \mathrm{O}_{40}-\mathrm{SiO}_{2}$, the reaction of benzonitrile was completed in $45 \mathrm{~min}$. Using an unsupported catalyst, this reaction was carried out in $8 \mathrm{~h}$ with $80 \%$ yield. These results show that supported and unsupported $\mathrm{H}_{4} \mathrm{SiW}_{12} \mathrm{O}_{40}$ accelerates the rate of reaction versus the action of $\mathrm{SiO}_{2}$ alone.

\section{Catalyst reusability}

The reusability of the catalyst is important for the large scale operation and from an industrial point of view. Therefore, the reusability of the catalysts was examined in the reaction of benzonitrile with ethylenediamine. Since the reaction medium is heterogeneous, the catalysts can be recovered by simple filtration after dilution of the reaction mixture with EtOH. The recovered catalysts were dried at $100{ }^{\circ} \mathrm{C}$ and weighed. Afterwards, according to the catalyst amount, the required amount of fresh nitrile and ethylenediamine were added. The results showed that the catalyst can be reused four consecutive times (Table 5).

Table 5. Reusability of $\mathrm{H}_{4} \mathrm{SiW}_{12} \mathrm{O}_{40}-\mathrm{SiO}_{2}$ in the reaction of benzonitrile with ethylenediamine

\begin{tabular}{ccc}
\hline Row & Time $(\min )$ & ${\text { Yields }(\%)^{\text {a }}}^{-1}$ \\
\hline 1 & 60 & 90 \\
2 & 60 & 90 \\
3 & 65 & 87 \\
4 & 65 & 85 \\
\hline
\end{tabular}

${ }^{\mathrm{b}}$ Isolated yields.

\section{Comparative results}

In order to show the ability of our method with respect to previous reports, some of our results in comparison to some other methods are summarized in table 6 . As shown, the yield/time ratios of the present method are better or comparable with the others. 
Table 6. Comparison of some our results with those reported in the litrature ${ }^{\mathrm{a}}$

\begin{tabular}{|c|c|c|c|c|c|}
\hline Entry & Product & $A^{b}$ & B & $\mathrm{C}$ & $\mathrm{D}$ \\
\hline 1 & & $90 / 45$ & $90 / 65$ & $100 / 180$ & 99 \\
\hline 2 & & $95 / 105$ & $88 / 115$ & - & - \\
\hline 3 & & $70 / 150$ & - & - & 99 \\
\hline 4 & & $85 / 135$ & $75 / 80$ & $94 / 180$ & - \\
\hline 5 & & $90 / 60$ & - & - & 80 \\
\hline 6 & & $60 / 220$ & $80 / 70$ & $99 / 180$ & - \\
\hline 7 & & $80 / 120$ & $95 / 75$ & $100 / 180$ & 96 \\
\hline
\end{tabular}

${ }^{\mathrm{a}}$ Values refer to yield(\%)/time(min for $\mathrm{A}, \mathrm{B}, 3 \mathrm{~h}$ for $\mathrm{C}$ and overnight for $\mathrm{D}$ ) ratios. In the $\mathrm{B}, \mathrm{C}$ and D methods were used aldehyde and ethylenediamine as substrates. ${ }^{\mathrm{b}} \mathrm{A}$ : Our method; $\mathrm{B}: \mathrm{I}_{2}, \mathrm{KI}$, $\mathrm{K}_{2} \mathrm{CO}_{3} / \mathrm{H}_{2} \mathrm{O}, 90^{\circ} \mathrm{C} ;{ }^{42} \mathrm{C}: \mathrm{I}_{2}, \mathrm{~K}_{2} \mathrm{CO}_{3} / \mathrm{t}-\mathrm{BuOH}, 70{ }^{\circ} \mathrm{C}, 3 \mathrm{~h} ;{ }^{45} \mathrm{D}$ : NBS/TBME, $0^{\circ} \mathrm{C}$, RT, overnight. ${ }^{41}$

\section{Conclusions}

A simple and efficient procedure for the synthesis of 2-imidazolines and bis-imidazolines has been developed. Mild reaction conditions, absence of solvent, moderate reaction times, easy and quick isolation of the products, good to excellent yields, recoverability and reusability of the heterogeneous catalyst and large scale applicability are the main advantages.

\section{Experimental Section}

General. Chemicals were purchased from Merck, Fluka and Aldrich chemical companies. All of the products were identified by comparison of their physical and spectral data with those of authentic samples. IR spectra were recorded on a Jasco IR-680 spectrophotometer. ${ }^{1} \mathrm{H}$ NMR spectra were obtained with a Bruker-Arance AQS $300 \mathrm{MHz}$ or a Bruker 400 Ultrasheilld (400 
$\mathrm{MHz}$ ) spectrometers. The calcination process was carried out by a (2000W) Carbolite-Elf-ly6B furnace.

\section{Preparation of the supported catalyst}

The silica gel supported $\mathrm{H}_{4} \mathrm{SiW}_{12} \mathrm{O}_{40}$ was prepared by mixing silica gel (1.6 g, Merck grade 40, $0.063-0.2 \mathrm{~mm})$ with a solution of acid $(0.40 \mathrm{~g})$ in distilled water $(20 \mathrm{~mL})$. The resulting mixture was stirred for $30 \mathrm{~min}$. After removal of water in a rotary evaporator, the solid powder was dried at $80{ }^{\circ} \mathrm{C}$ for $4 \mathrm{~h}$ followed by $4 \mathrm{~h}$ calcinations at $170{ }^{\circ} \mathrm{C}^{39}$.

\section{General procedure for the preparation of 2-imidazolines and bis-imidazolines}

A mixture of nitrile $(10 \mathrm{mmol})$, ethylenediamine or 1,2-propanediamine (40 mmol) and 20\% $\mathrm{H}_{4} \mathrm{SiW}_{12} \mathrm{O}_{40}-\mathrm{SiO}_{2}(0.6 \mathrm{~g})$ was heated under reflux for $45-220 \mathrm{~min}$. After completion of the reaction as indicated by TLC (eluent: EtOAc/MeOH, 4:1), the reaction mixture was cooled to room temperature and then ethanol was added. After stirring, the mixture was filtered and the solvent evaporated. The crude product (1) was recrystallized from cyclohexane, $\mathbf{8}$ and $\mathbf{1 0}$ were recrystallized from methanol and others were recrystallized from n-hexane giving the pure products in $75-95 \%$ yields based on the starting nitrile (Table 3). Spectroscopic data of new compounds:

2-(4-Hydroxyphenyl)-4,5-dihydro-1H-imidazole (Table 3, entry 13). Mp:300-302 ${ }^{\circ} \mathrm{C} ; \mathrm{R}_{\mathrm{f}}=$ 0.536 (ethyl acetate:methanol = 9:1); IR $(\mathrm{KBr}) v\left(\mathrm{~cm}^{-1}\right): 3323(\mathrm{~b}, \mathrm{OH}), 3201(\mathrm{NH}), 1613,1592$, 1503, 1186, 853; ${ }^{1} \mathrm{H}$ NMR (400 MHz, DMSO) $\delta(\mathrm{ppm}): 3.55$ (s, 4H, 2CH$), 3.40(\mathrm{~s}, 1 \mathrm{H}, \mathrm{NH})$, $6.70(\mathrm{~d}, 2 \mathrm{H}, \mathrm{ArH}), 7.61$ (d, 2H, ArH), 8.31 (s, 1H, OH). Anal. Calcd. for $\mathrm{C}_{9} \mathrm{H}_{10} \mathrm{~N}_{2} \mathrm{O}: \mathrm{C} 66.65, \mathrm{H}$ 6.21, N 17.27; found: C 66.5, H 6.3, N 17.2.

2-(4-Chlorophenyl)-4,5-dihydro-4-methyl-1H-imidazole (Table 3, entry 14). Mp:150-152 ${ }^{\circ} \mathrm{C}$; $\mathrm{R}_{\mathrm{f}}=0.464$ (ethyl acetate:methanol = 9:1); IR $(\mathrm{KBr}) v\left(\mathrm{~cm}^{-1}\right): 3100(\mathrm{NH}), 2953,1600,1583,1479$, 1368, 1331, 831; ${ }^{1} \mathrm{H}$ NMR (400 MHz, DMSO) $\delta(\mathrm{ppm}): 1.27\left(\mathrm{~d}, 3 \mathrm{H}, \mathrm{CH}_{3}\right), 3.33\left(\mathrm{~m}, 2 \mathrm{H}, \mathrm{CH}_{2}\right)$, $3.92(\mathrm{~m}, 1 \mathrm{H}, \mathrm{CH}), 4.25$ (s, 1H, NH), 7.55-7.85 (dd, 4H, ArH). ${ }^{13} \mathrm{C}$ NMR (400 MHz, DMSO) $\delta(\mathrm{ppm}): 22.23, \quad 56.47,57.34,126.92,128.77,129.6,138.55$, 162.06. Anal. Calcd. for $\mathrm{C}_{10} \mathrm{H}_{11} \mathrm{ClN}_{2}$ : C 61.70, H 5.70, N 14.39; found: C 61.6, H 5.8, N 14.3.

2-(3-Chlorophenyl)-4,5-dihydro-4-methyl-1H-imidazole (Table 3, entry 15). Mp:147-149 ${ }^{\circ} \mathrm{C}$; $\mathrm{R}_{\mathrm{f}}=0.500$ (ethyl acetate:methanol = 9:1); IR (KBr) $v\left(\mathrm{~cm}^{-1}\right): 3120(\mathrm{NH}), 2962,1592,1542,1490$; ${ }^{1} \mathrm{H}$ NMR (400 MHz, DMSO) $\delta(\mathrm{ppm}): 1.14\left(\mathrm{~d}, 3 \mathrm{H}, \mathrm{CH}_{3}\right), 3.18\left(\mathrm{t}, 1 \mathrm{H}, \mathrm{CH}_{2}\right), 3.37(\mathrm{~s}, 1 \mathrm{H}, \mathrm{NH})$, $3.75\left(\mathrm{t}, 1 \mathrm{H}, \mathrm{CH}_{2}\right), 3.97(\mathrm{~m}, 1 \mathrm{H}, \mathrm{CH}), 7.43-7.91(\mathrm{~m}, 4 \mathrm{H}, \mathrm{ArH}) .{ }^{13} \mathrm{C} \mathrm{NMR}(400 \mathrm{MHz}, \mathrm{DMSO})$ $\delta(\mathrm{ppm}): 22.11,56.75,57.99,123.36,124.47,125.82,127.29,130.36,133.20,161.42$. Anal. Calcd. for $\mathrm{C}_{10} \mathrm{H}_{11} \mathrm{ClN}_{2}$ : C 61.70, H 5.70, N 14.39; found: C 61.8, H 5.8, N 14.5.

2-(4-Hydroxyphenyl)-4,5-dihydro-4-methyl-1H-imidazole (Table 3, entry 16). Mp:148-150 ${ }^{\circ} \mathrm{C} ; \mathrm{R}_{\mathrm{f}}=0.587$ (ethyl acetate:methanol =9:1); IR (KBr) v( $\left.\mathrm{cm}^{-1}\right): 3350(\mathrm{~b}, \mathrm{OH}), 3188(\mathrm{NH}), 2998$, 1591, 1184, 856; ${ }^{1} \mathrm{H}$ NMR (400 MHz, DMSO) $\delta(\mathrm{ppm}): 1.19\left(\mathrm{~d}, 3 \mathrm{H}, \mathrm{CH}_{3}\right), 3.23\left(\mathrm{dd}, 1 \mathrm{H}, \mathrm{CH}_{2}\right)$, $3.80\left(\mathrm{t}, 1 \mathrm{H}, \mathrm{CH}_{2}\right), 4.23(\mathrm{~m}, 1 \mathrm{H}, \mathrm{CH}), 4.42(\mathrm{~s}, 1 \mathrm{H}, \mathrm{NH}), 4.72(\mathrm{~s}, 1 \mathrm{H}, \mathrm{OH}), 6.70(\mathrm{~d}, 2 \mathrm{H}, \mathrm{ArH}), 7.64$ (d, 2H, ArH). ${ }^{13} \mathrm{C}$ NMR (400 MHz, DMSO) $\delta(\mathrm{ppm}): 21.81,53.42,54.67,114.25,116.72$, 
130.20, 163.20, 165.57. Anal. Calcd. for $\mathrm{C}_{10} \mathrm{H}_{12} \mathrm{~N}_{2} \mathrm{O}$ : C 68.16, H 6.86, N 15.90; found: C 68.2, $\mathrm{H}$ $6.8, \mathrm{~N} 15.8$.

\section{Acknowledgements}

The partial support of this work by Yasouj University is acknowledged.

\section{References}

1. Moffat, J. B. In The Surface and Catalytic Properties of Heteropolyoxometalates; Kluwer: New York, 2001.

2. (a) Kozhevnikov, I. V. Chem. Rev. 1998, 98, 171. (b) Okuhara, T.; Mizuno, N.; Misono, M. Adv. Catal. 1996, 41, 113.

3. (a) Kozhhevnikov, I. V. in Catalysis for Fine Chemical Synthesis, Catalysis by Polyoxometalates 2; Derouane E. Eds.; Wiley: New York, 2002. (b) Romanelli, G. P.; Bennardi, D.; Ruiz, D. M.; Baronetti, G.; Thomas, H. J.; Autino, J. C. Tetrahedron Lett. 2004, 45, 8935 .

4. Firouzabadi, H.; Iranpoor, N.; Amani, K. Synthesis 2003, 408.

5. (a) Kaur, J.; Griffin, K.; Harrison, B.; Kozhevnikov, I. V. J. Catal. 2002, 208, 448; (b) Lan, K.; Fen, S.; Shan, Z.-X. Aust. J. Chem. 2007, 60, 80.

6. (a) Azizi, N.; Torkiyan, L.; Saidi, M. R. Org. Lett. 2006, 8, 2079. (b) Rasalkar, M. S.; Bhilare, S. V.; Deorukhkar, A. R.; Darvatkar, N. B.; Salunkhe, M. M. Can. J. Chem. 2007, 85, 77. (c) Wang, E.; Huang, T.-K.; Shi, L.; Li, B.-G.; Lu, X.-X. Synlett 2007, 2197.

7. Firouzabadi, H.; Iranpoor, N.; Jafari, A. A. J. Organomet. Chem. 2005, 690, 1556.

8. Azizi, N.; Saidi, M. R. Tetrahedron 2007, 63, 888.

9. Dias, A. S.; Lima, S.; Pillinger, M.; Valente, A. A. Carbohydr. Res. 2006, 341, 2946.

10. Kozhevnikov, I. V.; Sinnema, A.; Jansen, R. J. J.; Pamin, K.; Van Bekkum, H.; Catal. Lett. 1995, 30, 241.

11. Kozhevnikov, I. V.; Kloetstra, K. R.; Sinnema, A.; Zandbergen, H. W.; van Bekkum, H. J. Mol. Catal. A: Chem 1996, 114, 287.

12. Rafiee, E.; Shahbazi, F. J. Mol. Catal. A: Chem 2006, 250, 57.

13. Torviso, M. R.; Alesso, E. N.; Moltrasio, G. Y.; V`azquez, P. G.; Pizzio, L. R.; C`aceres, C.V.; Blanco, M. N. Appl. Catal. A 2006, 301, 25.

14. Rafiee, E.; Rashidzadeh, S.; Azad, A. J. Mol. Catal. A: Chem. 2006, 261, 49.

15. Zhang, F. M.; Wang, J.; Yuan, C. S.; Ren, X. Q. Catal. Lett. 2005, 102, 171.

16. Izumi, Y.; Hisano, K.; Hida, T. Appl. Catal. A 1999, 181, 277.

17. Schorderet, M. In Pharmacologie: Des Concepts Fondamentaux aux Applications The'rapeutiques; Frison-Roche:Paris, 1992; pp 130-153. 
18. Le Bihan, G.; Rondu, F.; Pele-Tounian, A.; Wang, X.; Lidy, S.; Touboul, E.; Lamouri, A.; Dive, G.; Huet, J.; Pfeiffer, B.; Renard, P.; Guardiola-Lemaitre, B.; Manechez, D.; Penicaud, L.; Ktorza, A.; Godfroid, J.-J. J. Med. Chem. 1999, 42, 1587.

19. Vizi, E. S. Med. Res. Rev. 1986, 6, 431.

20. Li, H. Y.; Drummond, S.; De Lucca, I.; Boswell, G. A. Tetrahedron 1996, 52, 11153.

21. Ueno, M.; Imaizumi, K.; Sugita, T.; Takata, I.; Takeshita, M. Int. J. Immunopharmacol. 1995, 17, 597.

22. (a) Jones, R. C. F.; Nichols, J. R. Tetrahedron Lett. 1990, 31, 1771-1774; (b) Hayashi, T.; Kishi, E.; Soloshonok, V. A.; Uozumi, Y. Tetrahedron Lett. 1996, 37, 4969; (c) Jung, M. E.; Huang, A. Org. Lett. 2000, 2, 2659.

23. (a) Corey, E. J.; Grogan, M. J. Org. Lett. 1999, 1, 157; (b) Isobe, T.; Fukuda, K.; Araki, Y.; Ishikawa, T. Chem. Commun. 2001, 243.

24. (a) Jones, R. C. F.; Turner, I.; Howard, K. J. Tetrahedron Lett. 1993, 34, 6329; (b) Langlois, Y.; Dalko, P. I. J. Org. Chem. 1998, 63, 8107; (c) Jones, R. C. F.; Howard, K. J.; Snaith, J. S. Tetrahedron Lett. 1996, 37, 1707.

25. (a) Corey, E. J.; Grogan, M. J. Org. Lett. 1999, 1, 157; (b) Isober, T.; Fukuda, K.; Araki, Y.; Ishikawa, T. Chem. Commun. 2001, 243.

26. (a) Botteghi, C.; Schionato, A.; Chelucci, G.; Brunner, H.; Kurzinger, A.; Obermann, U. $J$. Organomet. Chem. 1989, 370, 17; (b) Morimoto, T.; Tachibana, K.; Achiwa, K. Synlett 1997, 783; (c) Davinport, A. J.; Davies, D. L.; Fawcett, J.; Russell, D. R. J. Chem. Soc., Perkin Trans. 1 2001, 1500; (d) Menges, F.; Neuburger, M.; Pfaltz, A. Org. Lett. 2002, 4, 4713; (e) Boland, N. A.; Casey, M.; Hynes, S. J.; Matthews, J. W.; Muller-Bunz, H.; Wilkes, P. Org. Biomol. Chem. 2004, 2, 1995.

27. Vorbrueggen, H.; Krolikiewicz, K. Tetrahedron Lett. 1981, 22, 4471.

28. Neef, G.; Eder, U.; Sauer, G. J. Org. Chem. 1981, 46, 2824.

29. (a) Korshin, E. E.; Sabirova, L. L.; Akhmadullin, A. G.; Levin, Y. A. Russ. Chem. Bull. 1994, 43, 431. (b) Levesque, G.; Gressier, J.-C.; Proust, M. Synthesis 1981, 963; (c) Oxely, P.; Short, W. F. J. Chem. Soc. 1947, 497. (d) Sonn, A. German Patent 616,227, 1935; Chem. Abstr. 1978, 30, 478, 4313. (e) Rousselet, G.; Capdevielle, P.; Maumy, M. Tetrahedron Lett. 1993, 34, 6395. (f) Forsberg, J. H.; Spaziano, V. T.; Balasubramanian, T. M.; Liu, G. K.; Kinsley, S. A.; Duckworth, C. A.; Poteruca, J. J.; Brown, P. S.; Miller, J. L. J. Org. Chem. 1987, 52, 1017. (g) Corbel, J. C.; Uriac, P.; Huet, J.; Martin, C. A. E.; Advenier, C. Eur. J. Med. Chem. 1995, 30, 3. (h) Mohammadpoor-Baltork, I.; Abdollahi-Alibeik, M. Bull. Korean Chem. Soc. 2003, 24, 1354. (i) Mirkhani, V.; Moghadam, M.; Tangestaninejad, S.; Kargar, H. Tetrahedron Lett. 2006, 47, 2129. (j) Mirkhani, V.; Mohammadpoor-Baltork, I.; Moghadam, M.; Tangestaninejad, S.; Abdollahi-Alibeik, M.; Kargar, H. Appl. Catal. A 2007, 325, 99. (k) Pathan, M. Y.; Paike, V. V.; Pachmase, P. R.; More, S. P.; Ardhapure, S. S.; Pawar, R. P. Arkivoc 2006, (xv), 205.

30. Hill, A. J.; Johnston, J. V. J. Am. Chem. Soc. 1954, 76, 922.

31. Salgado-Zamora, H.; Campos, E.; Jimenez, R.; Cervantes, H. Heterocycles 1998, 47, 1043. 
32. Boland, N. A.; Casey, M.; Hynes, S. J.; Matthews, J. W.; Smyth, M. P. J. Org. Chem. 2002, $67,3919$.

33. Shin, G. I.; Lee, J. I.; Kim, J.-H. Bull. Korean Chem. Soc. 1996, 17, 29.

34. Ramalingam, B.; Neuburger, M.; Pfaltz, A. Synthesis 2007, 572.

35. Weber, L. Disc. Today 2002, 7, 143.

36. Domling, A. Curr. Opin. Chem. Biol. 2002, 6, 306.

37. Kappe, C. O. Acc. Chem. Res. 2000, 33, 879.

38. Ugi, I.; Werner, B.; Dömling, A.; Molecules 2003, 8, 53.

39. (a) Misono, M.; Misono, N.; Katamura, K.; Kasai, A.; Konishi, Y.; Sakata, K.; Okuhara, T.; Yoneda, Y. Bull. Chem. Soc. Jpn. 1982, 55, 400. (b) Chang, T. H. J. Chem. Soc., Faraday Trans. 1995, 91, 375. (c) Fournier, M.; Thouvenot, R.; Rocchiccioli-Deltcheff, C. J. Chem. Soc., Faraday Trans. 1991, 87, 349. (d) Yadav, G. D.; Kirthivasan, N. J. Chem. Soc., Faraday Trans. 1995, 91.

40. Biela'nski, A.; Luba'nska, A.; Po'zniczek, J.; Micek-Ilnick, A. Applied Catalysis A 2003, 238, 239.

41. Fujioka, H.; Murai, K.; Kubo, O.; Ohba, Y.; Kit, Y. Tetrahedron 2007, 63, 638.

42. Gogoi, P.; Konwar, D. Tetrahedron Lett. 2006, 47, 79.

43. Mohammadpoor-Baltork, I.; Moghadam, M.; Tangestaninejad, S.; Mirkhani, V.; Hojati, S. F. Polyhedron 2008, 27, 750.

44. Jnaneshwara, G. K.; Deshpande, V. H.; Bedekar, A. V. J. Chem. Res. (S) 1999, 252.

45. Ishihara, M.; Togo, H. Synlett 2006, 227. 